\title{
Family Memory and Private Archives in the Soviet Twentieth Century*
}

\author{
Igor Narsky
}

Like his grandfather Gora, a legal practitioner in Leningrad, Pusin was interested in newspapers. He was leafing through the copy of Pravda that Abram had brought with him when he stumbled upon an article about the Zionists and how harmful their ideas were for Communism. And so, out of the blue, he discovered to his horror that Zionists were the same as "Jews." He already knew that his grandfather Abram was Jewish, but he had never paid it any attention. Yet now it turned out that he too was an enemy, a Zionist. Abram set about reassuring him, pointing out that the fact that Basia [the nickname given to Agniia Stefanovna Pukhal'skaia] descended from "the nobility" did not make her an enemy. Pusin seemed to calm down, but thought about what he had heard. ...

As usual, the arrival of Yura meant that it was Yasik's birthday. He was turning three. The first question Pusin asked him was: "So, Yura, are you of Jewish or noble origin?" Stunned, Yura replied, "You know, I think I'm more Jewish."1

I first heard this story long before I learned that it was mentioned in the memoirs of one of my distant relatives. This exchange, which must be understood in the context of rising anti-Semitism in the Soviet Union, took place in a dacha near

This article was translated from the French by Michael C. Behrent.

* This article is accompanied by photographs available under the heading "Complementary Reading" on the Annales website: http://annales.ehess.fr.

1. Agniia Stefanovna Pukhal'skaia, “Zhizn' sem’i Abrama Khazanova i Basi Pukhal'skoi” (unpublished manuscript, Moscow, 2006). 
Moscow in July 1976. ${ }^{2}$ The story's characters are: Basia, the author of the memoir; her husband Abram; their daughter-in-law's father, Gora; their daughter's husband, Yura; their seven-year-old grandson from Leningrad, Pusin; and another grandson from Sverdlovsk, Yasik. Before this article begins, it is important to note the lightheartedness with which the grandfather reminds his grandson of his grandmother's noble origins, as if such a trait were self-evident in the Soviet Union of the 1970s, a decade before Mikhail Gorbachev launched glasnost. The grandfather's frankness can be explained, on the one hand, by the fact that Abram and Basia's family had assembled a sizable archive containing concrete evidence of Basia's noble origins and, on the other hand, by the fact that these archives were frequently used during family exchanges, including those with small grandchildren. Two sets of family archives, including memoirs belonging to my distant relatives, provide the subject of this article.

I discovered these documents largely by accident while working on a project devoted to family history. ${ }^{3}$ While the women who assembled, preserved, and created them did not know each other personally until recently, their life trajectories-and consequently the construction of the archives-as well as the broad narrative structure of their memoirs nonetheless share many traits. The texts and objects preserved in the archives of Agniia Stefanovna Pukhal'skaia and Vera Afanasievna Khar'kova are ego-documents consisting of "words or statements that offer information, however rudimentary or oblique, on the way individuals perceive themselves, deliberately or inadvertently, in a family, community, country, or social milieu, or which reflect a person's attitudes toward these systems and the changes they experience. They must justify individuals' behavior, reveal their fears, expose their knowledge, shed light on their values, [or] reflect their life experiences and expectations." ${ }^{4}$ Ego-documents thus appear as an invaluable resource for scholars studying the daily lives and "object world" (Lebenswelt) of the silent majority of those "ordinary" participants in history. ${ }^{5}$

This article adopts a different approach from the dominant historiographical trend drawing on personal testimonies to study the Soviet past, which has focused

2. On anti-Semitism in the Soviet Union during this period, see Matthias Messmer, Sowjetischer und postkommunistischer Antisemitismus: Entwicklungen in Russland, der Ukraine und Litauen (Constance: Hartung-Gorre, 1997); Heiko Haumann, Geschichte der Ostjuden (Munich: Deutscher Taschenbuch Verlag, 1999); Zvi Y. Gitelman, A Century of Ambivalence: The Jews of Russia and the Soviet Union, 1881 to the Present (Bloomington: Indiana University Press, 2001); and Yuri Slezkine, The Jewish Century (Princeton: Princeton University Press, 2004).

3. Igor Narsky, Fotokartochka na pamiat': Semeinye istorii, fotograficheskie poslaniia i sovetskoe detstvo (Avtobio-istorio-graficheskii roman) (Chelyabinsk: Entsiklopedia, 2008).

4. Winfried Schulze, ed., Ego-Dokumente: Annäherung an den Menschen in der Geschichte (Berlin: Akademie Verlag, 1996), 28.

5. Personal testimonies play an important role in the study of Soviet daily life, the private sphere, and subjectivity. See: Sheila Fitzpatrick, Everyday Stalinism: Ordinary Life in Extraordinary Times: Soviet Russia in the 1930s (New York: Oxford University 
primarily on the first half of the twentieth century, particularly Stalinism. Scholars have set aside the testimonials of powerful men (Vyacheslav Molotov, Lazar Kaganovich, and Nikita Khrushchev) in order to study "ordinary people," of which the now classic case is the diary of Stepan Podlubny. ${ }^{6}$ Recently, interest in women's memoirs has grown, but in most cases the heroines of these books are either the regime's official icons, as were the pilots Marina Raskova and Marina Chechneva, ${ }^{7}$ or spokespersons of the Soviet dissident movement, such as Irina Erenburg, Yevgeniia Ginzburg, or Nadezhda Joffe. Memoirs from private archives written by men and even more often by women are rarely used and largely unknown. In this historiography, subjectivity is considered from a number of perspectives. By studying Soviet identity building, scholars have shed light on the ambivalent "vertical" relationships between, on the one hand, individuals for whom hypocrisy and cynicism were essential to survival and, on the other hand, a mistrustful state prone to violence. The state ascribed social status, while individuals assumed facades or masks, which allowed them to adopt the social categories prescribed by the regime. ${ }^{8}$ Other scholars, partially inspired by Michel Foucault's concept of "technologies of the self," have drawn on the analysis of personal documents to demonstrate how individuals fashioned themselves as perfect Soviet citizens. These studies reveal the ways in which people internalized the norms and values of official discourse and transformed them into categories of action. ${ }^{9}$ Finally, a more recent approach emphasizes the horizontal relationships between actors, demonstrating that interactions with close friends and family were central to opinion-making. Subjectivity was thus shaped by vertical and horizontal relationships at the same time. ${ }^{10}$

My own approach consists not merely in shifting the chronological framework or the particularities of the genre. Rather than studying the influence of political

6. Jochen Hellbeck, ed., Tagebuch aus Moskau, 1931-1939 (Munich: Deutscher Taschenbuch Verlag, 1996).

7. See, for example, Carmen Scheide, Vom Bubikopf zur Dauerwelle, Selbst- und Fremdbilder sowjetischer Nachthexen (2007), http://isem.susu.ac.ru/archen/fliegerinnen_de/.

8. See Fitzpatrick, Everyday Stalinism; Fitzpatrick, Tear Off the Masks! Identity and Imposture in Twentieth-Century Russia (Princeton: Princeton University Press, 2005). This work has been very popular among Russian scholars working on daily life and identity building. See: Elena A. Osokina, Za fasadom stalinskogo izobiliia: Raspredelenie i rynok v snabzhenii naseleniia v gody industrializatsii, 1928-1941 (Moscow: RosspèN, 1998); Natalia B. Lebina, Porsednernaia zhizn' sovetskogo goroda: Normy i anomalii, 1920-1930 gody (Saint Petersburg: Kikimora/Neva/Letnii sad, 1999); Oleg Kharkhordin, Oblichat' i litsemerit': Genealogiia rossiiskoi lichnosti (Saint Petersburg: Letnii sad, 2002); and Igor Narsky, Zhizn'v katastrofe: Budni naseleniia Urala v 1917-1922 gg (Moscow: Rosspè̀, 2001).

9. Hellbeck, Tagebuch; Igal Halfin, Intimate Enemies: Demonizing the Bolshevik Opposition, 1918-1928 (Pittsburgh: University of Pittsburgh Press, 2007); Véronique Garros et al., eds., Intimacy and Terror: Soviet Diaries of the 1930s (New York: The New Press, 1995); Brigitte Studer and Berthold Unfried, Der stalinistische Parteikader: Identitätsstiftende Praktiken und Diskurse in der Sowjetunion der Dreissiger Jahre (Cologne: Böhlau, 2001); and Irina Paperno, Stories of the Soviet Experience: Memoirs, Diaries, Dreams (Ithaca: Cornell University Press, 2009).

10. Malte Griesse, Communiquer, juger et agir sous Staline. La personne prise entre ses liens avec les proches et son rapport au système politico-idéologique (Frankfurt: Peter Lang, 2011). 
circumstances, the discourses of power, and social environment on collective and individual identity building, I propose to analyze the impact of the objects that individuals handled on a daily basis. I am less interested in the world of objects that are exhaustively described in women's memoirs, be they apartment interiors or items used in daily life (clothing, shoes, toys, radio sets, maps, books, or magazines), than artifacts that have been directly inserted into texts (photographs, copies of documents, fragments of letters, unpublished diaries, etc.) and for the most part preserved in family archives. Why did the authors of these memoirs include photographs, extracts from letters, official documents, and private papers in their texts? Does this practice shed light on the mechanisms of identity building and preservation, as well as the daily practices of family interaction in the Soviet Union, which are so difficult to glean from other sources? Did family commemorative practices have any specifically "Soviet" traits? Did they break with prerevolutionary practices of private commemoration?

In order to answer these questions, two theoretical frameworks have proven useful. The first, tied to phenomenological sociology, asserts that one of the main reasons people construct autobiographical accounts is to present a picture of a happy life. These narratives may be verbal or visual and are constructed, for instance, through photo albums. ${ }^{11}$ This theory has been convincingly applied in sociological and historical studies. ${ }^{12}$ The second theory, which originates in anthropology, posits that the objects used by families on a daily basis can serve as important instruments and materials for building, preserving, and rebuilding family memory and identity. Everything that is shaped by the individual's history, including the world of objects, becomes a symbol of the actor's identity. Objects invested with particularly deep symbolic significance may become "relics," ${ }^{13}$ by which I mean symbols referring to phenomena and representations. They pose a central symbolic problem, which is that of the common language used during the interactions they create and in which they play a role. According to the philosopher of communications Vilém Flusser, codes built on the basis of symbols are bridges between human beings and the world. They "signify" the world. At the same time, they serve as bridges between people: they must signify the world to others, thus signifying the world on the basis of mutual understanding. Any consensus about meaning must, in turn, be meaningful. ${ }^{14}$ In other words, the incorporation of objects

11. Alfred Schütz and Thomas Luckmann, Strukturen der Lebenswelt (Frankfurt: Suhrkamp, 1975; repr. 1994); Peter L. Berger and Thomas Luckmann, Die gesellschaftliche Konstruktion der Wirklichkeit: Eine Theorie der Wissenssoziologie (Frankfurt: Fischer Taschenbuch Verlag, 1999).

12. For example, see: Merridale, Night of Stone; Stefan Guschker, Bilderwelt und Lebenswirklichkeit: eine soziologische Studie über die Rolle privater Fotos für die Sinnhaftigkeit des eigenen Lebens (Frankfurt: Peter Lang, 2002), 279-80.

13. On the role of objects in identity building, see: David Lowenthal, The Past is a Foreign Country (Cambridge: Cambridge University Press, 1985); Maurice Godelier, The Enigma of the Gift, trans. Nora Scott (Chicago: University of Chicago Press, 1999). 1998), 76-77. 
into a narrative can signify an effort to create, verify, and strengthen agreement about the world's meaning between the narrative's authors and its audience. In the case studied here, the object of this agreement is the shared past within the family circle.

\section{The Memoirs' Authors: Biographical Milestones}

Both Agniia Stefanovna Pukhal'skaia (born in 1918) and Vera Afanasievna Khar'kova (born in 1922) belonged to the first generation of children born in Soviet Russia. At the very beginning of her memoir, Khar'kova refers to the changes she has lived through: "I witnessed and participated in every stage of the life of the Soviet Union, and I lived very differently from the way one lives in Russia today." 15 Their mothers were both daughters of Orthodox priests. Having received solid educations during the tsarist era, they worked as secondary school teachers during the Soviet period. Pukhal'skaia's mother, Agniia Ivanovna Bulgakova (1890-1975), finished high school (or gimnaziia) before studying at the Bestuzhev women's college in Saint Petersburg, which was renowned for its progressive teachers and liberal spirit. Khar'kova's mother, Anastasia Vladimirovna Narskaia (1900-1986), graduated from the Mary Diocesan School in Moscow, which offered priests' daughters an education comparable to that of a gimnasiia. The memoirists' fathers belonged to two different generations of Russian revolutionaries. Pukhal'skaia and Khar'kova devoted several years to writing their biographies. Stefan (Stepan Iosifovich) Pukhal'skii (1883-1921), a Polish Catholic nobleman, was actively involved in the Polish Social-Democratic movement and in the 1917 revolutions in the Volga region. He joined the (internationalist) Russian Social Democratic Workers' Party in 1917 and the Bolsheviks in 1920. He died suddenly of apoplexy in October 1921. His death may have been tied to the great purge of the Russian Communist Party, which began a month prior to his death and resulted in the exclusion of one out of every four Communists. ${ }^{16}$ According to the testimonials Khar'kova assembled, Afanasii Ivanovich Khar'kov (1902-1940) came from a military family. After participating in the First World War, he became a "red" hero and was decorated on several occasions for his military achievements during the Civil War. He organized collectivization in Moscow and the Volga before being repressed in 1936 and dying several years later in a far-eastern camp. Pukhal'skaia was three when she lost her father, and Khar'kova was fourteen. The loss of their fathers, who were both thirtyeight when they died, was compensated by the role played in their lives by their maternal grandmothers. Indeed, Elizaveta Vasilievna Bulgakova (née Popova,

\footnotetext{
15. Vera Afanasievna Khar'kova, "Vospominaniia rossiianki, rodivsheisia v 1922 godu" (unpublished manuscript, Saint Petersburg, 2001).

16. The purge of the Russian Communist Party, which took place from September to December 1921, was provoked by the fear that the party had been contaminated by "socially alien" elements. It resulted in a steep decline in party membership, which dropped from 732,000 to 410,000 members.
} 
1858-1944) and Anna Dmitrievna Narskaia (Vozdvizhenskaia, 1869-1946) were critical figures in their granddaughters' education. Both memoirists attended college in Moscow, Pukhal'skaia at the Textile Institute (1936-1942) and Khar'kova at Plekhanov's Institute of the National Economy (1939-1943). Due to the gendered distribution of social roles in Soviet society, which offered "neither tradition nor emancipation," 17 they faced the dual burden of work and domestic responsibilities. Both gave up their careers to have children (three each) and support their husbands: Abram Pavlovich Khazanov (1918-2000), an economic leader, and Georgii Georgievich Pavlov (1906-1973), a former officer, World War II veteran, and scientist. One of them lost a child. Not until much later, at the dawn of the third millennium, did they begin to write their long and detailed family histories.

\section{Archive Histories and Family Memoirs}

Pukhal'skaia and Khar'kova wrote their memoirs at a time when the past was a topic of intense interest in the former Soviet Union, when the government attempted to impose its own historical interpretation and genealogy became fashionable as people sought to uncover their noble origins. ${ }^{18}$ In explaining why these two women assembled their archives and souvenirs, it is very tempting to refer to this context. Yet their memoirs and the interviews I conducted with them between 2005 and 2010 suggest a more complex story unfolding over a longer time period. In the 1940 s, both women left the houses in which they were born, and this was the trigger and starting point for assembling family archives. In Pukhal'skaia's case, her departure from Kalinin (which is now Tver) in the fall of 1941 due to advancing German troops was sudden and involuntary. She brought almost nothing with her. Following the evacuation, a German bombardment set off a fire that completely destroyed the Pukhal'skaia family's apartment, including all their property: letters, photo albums, piano, and dishes. ${ }^{19}$ Having moved to Tashkent, Uzbekistan, she had to start over from scratch, reassembling the body of documents related to her children and her loved ones who remained in Moscow. These papers from the forties became a significant portion of her family archives and provided her with a solid basis for writing her memoirs.

Khar'kova was separated from her family in the summer of 1946 when she married Pavlov, moving from the area around Moscow to Leningrad, where her husband lived and worked. During the war, Vera Afanasievna and Georgii

17. Susanne Conze, "Weder Emanzipation noch Tradition: Stalinistische Frauenpolitik in den vierziger Jahren," in Stalinismus: Neue Forschungen und Konzepte, ed. Stefan Plaggenborg (Berlin: A. Spitz, 1998), 293-320.

18. The wave of genealogies of noble families that were published at the time attests to the genealogy boom that occurred in Russian in the 1990s. See, for example, Izvestiia Russkogo genealogicheskogo obshchestva 1 (1994): 45-91, and 6 (1994): 87-108.

19. On evacuation difficulties in the eastern regions, see Rebecca Manley, To the Tashkent 
Georgievich corresponded intensely. Her preservation of and comments on this exchange are the origin of her family archive and memoirs. In both cases, the actual writing of the memoirs was preceded by preparatory work-beginning in the 1960s, in Pukhal'skaia's case, and the 1970s, in Khar'kova's-which lasted several decades. They began to gather information because they wanted to learn more about their fathers. Though both men's deaths were tied to specific political events, neither account can be described as "political" per se. Consequently, it would be wrong to say that reconstructing their family history was a pretext for undertaking a personal reinterpretation of the country's political history.

Beginning in the 1960s, S. Pukhal'skii's daughter, Agniia (Basia), began actively collecting materials relating to her father's life, profession, and work. She assembled the memories of people who knew and remembered him: L. I. Zakharova, V. Moroshkin, his sisters Sofiia and Ianina, his wife A. I. Pukhal'skaia, I. F. Formozov, etc. Much to my despair, all the papers that remained after S. I. Pukhal'skii's death, and which might have spoken for him, were burned along with the house on Volnyi Novgorod Street in Kalinin in mid-October 1941. Basia thus gathered everything she could to reconstruct a living image of her father. The archives of Moscow State University were used. From these archives, Abram managed to get a copy of S. I. Pukhalskii's personal student file. Basia studied every issue of the Tver Pravda preserved in the Lenin State Library (as well as several others) from 1919 to 1921 and copied down the numerous articles and shorter pieces devoted to him, which she needed. The materials were collected from several places, including his correspondence, which was conserved for the years between 1911 and 1917. ${ }^{20}$

Pukhal'skaia switched from searching for material about her father to collecting information about every branch of her family. By her own admission, a solid foundation in genealogy and her Polish family members' zealous preservation of family history were critical. As permission to travel abroad became easier to obtain, her family began to organize reciprocal visits beginning in the 1960s. Their 1995 family reunion in Poland, which brought together some eighty family members from Poland, Russia, France, Great Britain, Indonesia, and Kuwait-in other words, over half of the Pukhal'skiis and their family members that were scattered across the world, including Pukhal'skaia and her younger children-was the most striking example of this genealogical fad. Though she had been doing it for years, Pukhal'skaia's work only became systematic and regular after her husband's death in 2000 .

Basia did not know what to do or how to get her mind off it, even for just a moment. [Her daughter] Elia suggested "genealogy," and Basia began to organize the materials she had collected and type into a computer systematized data relating to every branch of the family - the Khasanovs, the Gesentsveys, the Pukhalskiis, the Bulgakovs (the ZeleninPopovs) - and every relative. 
She suddenly had a completely new idea: to write a history of Abram Kha:anov and Basia Pukhal'skaia's family from 1936 to 2000.

Thus, there would be plenty to do for the rest of Basia's days, as long as her strength would allow it. ${ }^{21}$

Khar'kova went through a similar process over several years. After her husband's death, she began rewriting the letters he had sent from the front, some of which, because they had been written in pencil, were beginning to fade away. She supplemented this work with explanations, which resulted in a long text on their blissful love. Her desire to establish her family's history was also tied to a fear that the Khar'kovs' past could disappear: "The only reason I wrote my memoirs is for my descendants to know how and why." 22 Furthermore, beginning in the summer of 1973 and over the next thirty years, she would make an annual trip to Ermolino, near Moscow, where, before collectivization, she had spent every summer with her mother's parents as a little girl. She questioned friends and family about the Narsky family's past and collected and made copies of papers and family photographs. This work intensified during Perestroika, when Khar'kova discovered the circumstances in which her grandfather, the priest Vladimir Alekseevich Narsky (1868-1938), was executed by the People's Commissariat for Internal Affairs (NKVD) at Butovo, in the Moscow suburbs. ${ }^{23}$ Her childhood impressions of her priestgrandfather's family life had been very different from the stereotypes found in nineteenth-century Russian literature. She wanted to fight the clichés. It is also possible that the idea of committing her memories to paper developed unconsciously between 1980 and 1990. At this time, for several years she went each week to the House of Science Veterans of the city of Pushkin, where an old family friend of noble origins, Aleksandr Imshenik-Kondratovich, dictated his memoirs to her. When she retired in 1998, Khar'kova was able to devote herself to gathering documents and writing.

Pukhal'skaia and Khar'kova wrote their memoirs at the same time. The former devoted five years to the task (from 2000 to 2006), the latter three (from 2000 to 2003). In the end, the writing period was relatively brief, if one considers their lack of experience and the length of their texts - which are quite sizable, at respectively 1.6 million and a million characters in length. Their memoirs formed both the core of their rather extensive family archives and detailed inventories of their content, while also constituting the basic texts for preserving the family's memory and bequeathing its shared past to future generations.

21. Ibid., 182.

22. Interview with Vera Afanasievna Khar'kova, May 7, 2009.

23. The NKVD camp at Butovo was a site of mass repression. Between August 1937 and August 1938, more than 20,000 people were shot. See: Ernest A. Bakirov and Valerii P. Shantsev, eds., Butovskii poligon 1937-1938 gg: Kniga pamiati sherto politicheskikh repressii (Moscow: Institut eksperimental'noi sotsiologii, 1997-2004), 1-8; Karl Sclögel, Terror und Traum: Moskau 1937 (Munich: Carl Hanser, 2008). 


\section{The Contents of the Pukhal'skaia and Khar'kova Archives and Memoirs}

As elements of two massive family archives, Pukhal'skaia's and Khar'kova's memoirs are secondary sources derived from an array of primary sources, including official documents, genealogical charts and graphs, diaries, memoirs of close relatives and acquaintances, compositions for school written by children, as well as stories jotted down as notes, photo albums, letters, poems for festive occasions, the lyrics of favorite family songs, drawings, and family relics. Everything is arranged in boxes, binders, and albums organized by family or family member, period, and events. Pukhal'skaia's archives are noteworthy for the importance accorded to materials that are external to the family: official documents and popular publications, literary texts, and published memoirs written by her father or other ancestors. Both authors' archives occupy part of their bookcases, tables, walls, shelves, and the tops of chests of drawers. Given the increasing space their archives fill in their apartments, they worry about the future of their collections. ${ }^{24}$

Pukhal'skaia's memoirs, "The Life of the Family of Abram Khazanov and Basia Pukhal'skaia," are a chronological tale devoted to the family's history between 1936-when the author was admitted to the Moscow Textile Institute and met her future husband-and 2006, when her youngest child turned sixty (the retirement age). The description of family life is divided into large chapters based on the places they lived. The text is completed by genealogical descriptions of all branches of the family, which constituted the origin of her memoir-writing project. She typed the text herself on her computer after her loved ones had corrected it. Khar'kova's memoirs were written longhand in ninety-six-page notebooks of A4 graph paper. They consist of several partially overlapping memoirs, in which certain passages are repeated word for word. These are organized chronologically: "Biography of My Husband, Georgii Georgievich Pavlov" (213 manuscript pages); "Memoirs of a Russian Born in 1922" (385 pages); "A True History of the Great Patriotic War" (169 pages); "Memoirs of the Granddaughter of the Priest of Saint Nicholas's Church in the Village of Ermolino, Vladimir Alekseevich Narsky" (twenty-three pages); and "Episodes of my Life," from the 1940s until the 2000s, written on loose-leaf paper and in school math notebooks. The memoirs are not organized into chapters. The text, in a large, firm hand, sometimes runs on for several pages without a paragraph break.

"Memoirs of a Russian" is her longest (at 400,000 characters) and most detailed text. It is a story about happiness, in which the author relates the lives of her parents, her youth and young adulthood, how she met her future husband, how they fell in love, their early married life, and the birth of their first child. The account ends in 1946, when the small family moved to Leningrad. These memoirs

24. For more details on intergenerational conflicts related to the refusal of the elderly to let go of their old things, see Marina E. Eliutina, "Pozhilye liudi i starye veshchi v povsednevnoi zhizni," Sotsiologicheskie issledovaniia 7 (2009): 101-9. 
stand out because of their lively character and the wide range of themes they address. They describe her childhood and her life between the ages of fifteen and twenty-five-the period that, according to neurologists, leaves the most lasting memories. ${ }^{25}$ Her other memoirs, "Biography of My Husband" and "Memoirs of the Granddaughter," cover the following period up to 2003. Pukhal'skaia's and Khar'kova's writings cover the lives of two families over most of the twentieth century. They complete one another. While Khar'kova recounts events that took place primarily in Moscow and Leningrad, Pukhal'skaia's texts are set in Uzbekistan and Armenia between 1940 and 1970. The authors thus describe Soviet daily life from two different geographical standpoints: the capital and the provinces, on the one hand, and Russia and its national peripheries, on the other.

Pukhal'skaia deliberately uses the family "resources" that fill the lower shelves of several bookcases. Her text includes footnoted references to her family members' diaries-her mother's memories and postcards, but also notes that she wrote herself while traveling abroad and her children's writings about memorable events and impressions. In such ego-documents, which are so richly represented in Basia's family archives, the nineteenth-century tradition of diary keeping, questionnaires, and an album (it is no coincidence that this tradition was actively supported and preserved by Pukhal'skaia's mother) overlap with the Soviet practice of diary writing - particularly at school—which was seen as a tool for the (self) control, (self) discipline, and (self) education of the "new man." 26 Pukhal'skaia's memoirs also mention and even provide copies of documents tracing the major steps in the educational and professional careers of her family members, letters from the children after they left the paternal home (particularly the eldest son Stefan, or "Stiva"), and programs of family concerts, in addition to drawings by her husband, her youngest grandson, and herself. Conversely, Khar'kova appears convinced that her memoirs were written entirely from memory. They are strikingly vivid in their descriptions of events, impressions and feelings, despite their distance in time. Some details suggest, however, that she used documents to reconstruct and check her recollections. Khar'kova is able, for instance, to provide the exact dates on which her husband sent letters from the front, technical terms relating to her husband's many inventions, and specific praise for his work published in the Institute's journal for its jubilee. In fact, "Biography of My Husband" is preceded by a note openly acknowledging the sources that assisted her: "I drew on documents, accounts by my mother, Kseniia Ivanovna Pavlova, and by Georgii Georgievich himself." ${ }^{27}$ More importantly, the first manuscript versions of "Biography of My Husband" and "Memoirs of a Russian Born in 1922" are richly illustrated with photographs.

The texts' stylistic differences can be explained by each author's conception of the role of family archives with regard to memoir-writing. In Pukhal'skaia's case,

25. Guschker, Bilderwelt und Lebenswirklichkeit, 279-80.

26. Hellbeck, Tagebuch; Aleksandra Arkhipova, "Karl Marks i sovetskaia chkolnitsa," in SSSR: Territoriia liubvi, eds. Borisova et al. (Moscow: Novoe izdatel'stvo, 2008), 188-207. 
the style is deliberately official, dry, and almost completely lacking in literary flourishes. She writes about herself in the third person and frequently cites documents in order to establish the veracity of her memory and information. The text is full of sentences with verbs conjugated in the first or second person with no subject, as if they were self-evident. The author deliberately purges her narrative of all emotion. Yet when she mentions the people to whom she was closest, tragic occurrences, or events in which she participated or that she witnessed, emotions surface nonetheless, creating touching scenes. Concluding her account of the tragic year of 1996, when she suddenly lost her eldest son as well as his wife, she thus wrote:

Everything that happened is written with economy, without the details that pull on heartstrings. Yet there was such sobbing, crying, and weeping, particularly for Basia. Abram held back as well as he could, but his weak heart could not always bear it and he began suffering from high blood pressure. Doctors were always being called. But what could they do, confronted with the loss of a parent's most prized possession: Abram and Basia's eldest child, their cherished son Stiva-Stivusia-Stivushochek, had left them forever. ${ }^{28}$

Khar'kova wrote her memoirs very differently. She wrote quickly, with no interruptions, driven by a desire to commit what she had in her head to paper as quickly as possible. Her drafts (and sometimes even rewritten "clean" copies) often include bits of paper glued to the text indicating later emendations, which she had managed to "unearth" from the depths of her memory. She describes with considerable sensitivity not only events, but also the scents, sounds, thoughts, and even nocturnal dreams she associates with them. While writing her memoirs, as she confessed when I interviewed her, she relived her life. In the text, she uses an abundance of exclamation points and question marks when describing an emotional incident, the beauty of nature, joyous or tragic events, and strong impressions left by difficult times. In the following excerpt from "Memoirs of a Russian," for example, she describes her reaction to the death of her father, who was a victim of repression: "I did not expect such news! How horrible! Papa is no more! He died while I was having fun in Leningrad! So the letter I had received was written by someone else, as he was no longer among us! And I wrote the last two letters when he was already dead! Dear God, what hell! My dear little papa, is it possible that I will never see you again?" 29 A notable characteristic of "Memoirs of a Russian" is the repetition in various forms of the expression "I remember": "I remember well," "I clearly remember," "yet I do perfectly remember," etc. The author freely admits that there are some things that she does not remember at all. The antithesis between "I remember" and "I do not remember" is ultimately what makes the narrative persuasive-like when she says that she no longer remembers what meals she was served in kindergarten, yet clearly recalls her maternal grandparents' table manners at Ermolino. ${ }^{30}$

28. Pukhal'skaia, “Zhizn' sem'i," 369.

29. Khar'kova, "Vospominaniia rossiianki," 239-40.

30. Ibid., 92. 


\section{(Family) Memory}

To understand the role of private archives and narratives in the construction of family memory, one must briefly consider the state of the literature on memory as a social and cultural phenomenon. Currently, memory is typically associated with personal "archives": individuals are free to use as they see fit images from their past kept in repositories of their own making. This idea, as natural and "eternal" as it may seem, is in fact a relatively recent one. It coincides with the advent of modernity, when people emancipated themselves from religion and made demands in the name of reason and individualism. Today, the human sciences define memory as "an individual's capacity to locate his or her individual existence in a spatial and temporal unit and consider the past as that which precedes the present." 31 The study of memory as a collective, social, and cultural phenomenon began with Maurice Halbwachs's thesis that a society and social groups define the content and the structure of their members' memory. ${ }^{32}$ Despite the critiques leveled against the possibility of a single, homogeneous collective memory, his notion of collective memory as the external social framework needed to preserve group unity, identity, and social cohesion has informed recent work in the social sciences on memory, including in Russia and the Soviet Union. ${ }^{33}$ The growth of work on collective memory over the past thirty years has led to several tendencies. First, memory as a subjective phenomenon is no longer rigorously opposed to history as an "objective" scientific practice: the representation of history as a form of collective memory has become increasingly common. According to this vision, historians are both the guardians and, in a sense, the "prisoners" of the memory, myths, values, preferences, and interpretive stereotypes of the professional, ethnic, gender, and other communities to which they belong. ${ }^{34}$ Scholarly interest then shifted from the question of the content of memory to the problem of its use. The question "what is

31. Hans J. Markowitsch and Harald Welzer, Das autobiographische Gedächtnis: Hirnorganische Grundlagen und biosoziale Entwicklung (Stuttgart: Klett-Cotta, 2005), 11.

32. Maurice Halbwachs, Les cadres sociaux de la mémoire (Paris: Puf, 1935 ; repr. 1952); Halbwachs, La mémoire collective (Paris: Puf, 1950).

33. For example, see: Merridale, Night of Stone; Andreas Langenohl, Erinnerung und Modernisierung: Die öffentliche Rekonstruktion politischer Kollektivität am Beispiel des neuen Russlands (Göttingen: Vandenhoeck \& Ruprecht, 2000); Igor Narsky et al., eds., Vek pamiati, pamiat' veka: Opyt obrashcheniia s proshlym v 20 stoletii (Chelyabinsk: Kamennyi poias, 2004); and Malte Rolf, Das sowjetische Massenfest (Hamburg: Hamburger Edition, 2006).

34. For further information, see: Peter Burke, "History as Social Memory," in Memory: History, Culture, and the Mind, ed. Thomas Butler (New York: Blackwell, 1989), 97-113; Jörn Rüsen, "Geschichtskultur als Forschungsproblem," in Historische Orientierung, ed. Jörn Rüsen (Cologne: Böhlau, 1992), 235-45; Iuliia Khmelevskaia, "Vvedenie: O memorizatsii istorii i istorizatsii pamiati," in Narsky et al., Vek pamiati, 7-20; Patrick H. Hutton, History as an Art of Memory (Hanover/London: University of Vermont/ University Press of New England, 1993). 
it?" gave way to "how?" - a question that is difficult to answer without assistance from neuroscientists.

Memory specialists always return to the central metaphor of "archives." They are often more interested in how "owners" used these "archives" than in their contents. They also use the image of the "computer," which allows users to simply "download" recorded information without activating any emotions, as well as the metaphor of the "hologram," which suggests a novel way of interpreting the traces that particular events leave in the brain. In keeping with this "holographic" approach, changes in the brain resulting from past encodings or "imprints" left by remembered information-engrams_do not store an exact "record" of the past, but a fragment on the basis of which an event may be reconstructed in its entirety. Psychologists and neurologists, along with sociologists who have been influenced by their work, use the concept of "scenario" to emphasize that "the success of the operation of remembering is determined by both the reconstruction and the modification of the event. In this way, remembering resembles learning in that the latter consists not only in the reproduction of knowledge, but also its modification." 35 According to this approach, remembering is a creative action, connecting the past to a changing present in a way that renders the past changeable. Family memory is a kind of collective memory. As for any group, it guarantees unity and heritage through integration, communication, and family socialization. The family ultimately owes its existence to this work of remembering. According to Pierre Bourdieu, "the family is the product of an institutionalization, both ritual and technical, aimed at durably instituting in each member of the instituted unit feelings that will tend to ensure the integration that is the condition of the existence and persistence of the unit." ${ }^{36}$ Pukhal'skaia explicitly confirms this idea: "The family confronted new ways of living, new languages, new people, customs, climates, and types of nature so often that it might well have become a chameleon. But it remained itself, with its own way of life, and educated its children according to its own rules, in order to make them educated members of the intelligentsia, develop their talents and abilities, and ensure that they be themselves." 37

Pukhal'skaia's and Khar'kova's archives and memoirs are valuable sources for studying not only the memory of the prerevolutionary past during the Soviet period, but also the memory of the Soviet past, both under the Soviet Union and after its dissolution. They can help us to better understand the history of memory in several respects. First, their archives and memoirs allow us to see what elderly widows deemed sufficiently important in the early twenty-first century to be incorporated into the family's memory and what they chose to reject and pass over in silence. In both cases, traditional history is an "aside" to family history, whereas daily life, family members' destinies, and the love and education of one's children constitute the primary preoccupations. Pukhal'skaia's and Khar'kova's books of

35. Guschker, Bilderwelt und Lebenswirklichkeit, 268.

36. Pierre Bourdieu, Practical Reason: On the Theory of Action (Stanford: Stanford University Press, 1998), 67. This passage was translated by Richard Nice.

37. Pukhal'skaia, “Zhizn' sem'i,” 171. 
memories must be seen not merely as personal testimonies drawn from individual recollections, but as representations of their family's memorial culture, the fruit of long-term commemorative work in which numerous relatives participated as informants, interviewees, and readers. Secondly, the archives also shed light on the family's commemorative practices: diary keeping, photo albums, and family reunions for both joyous and sad occasions, during which memory revives past events and the recently deceased. Beginning in the 1970s, Pukhal'skaia's and Khar'kova's memoirs constantly evoke the deaths of friends and loved ones in addition to mourning rituals. The importance of the theme of mourning is a logical result of the deaths that occur with increasing frequency as one ages, but it is also related to the gendered roles assumed by the memoirists. Indeed, in ancient societies (including patriarchal ones), women tended to the family calendar, mourning rites, and the preservation of memory. ${ }^{38}$ These tasks were and remain a woman's preserve. Third, it is incumbent on a scholar interested in familal commemorative practices to understand the topics of oral communication within families during the Soviet period. As this article will examine, compromising stories often belonged to a family's heritage and the ways they circulated orally within families challenges the idea that Soviet families carefully hid their past from younger generations. ${ }^{39}$ Pukhal'skaia's and Khar'kova's memoirs reveal the details of how family memory was constructed under the USSR, the mechanics of family communication, and the potential for family integration, in addition to determining the role and purpose of the world of objects in family commemoration.

\section{Old Objects and "Real Effects"}

In her text, Khar'kova includes a rich collection of photographs. These pictures in various formats, which she culled from photo albums and arranged in transparent sleeves with captions, can be found on almost every page of the manuscript. The sleeves are stuck together with tape, and the photographs are placed across from the text, giving them an apparently illustrative role. They consist primarily of group photographs and, more rarely, individual portraits taken by both professional and amateur photographers. Some pictures, however, represent buildings-such as the Khar'kova family's dacha in Karelia between 1950 and 1970—or events, such as strawberry planting in the kolkhoz led by the author's father. Some of the photographs belonged to her relatives, but most were either taken by her, her husband, and her children or came from her friends' archives and were gathered together over the years. In this category, one finds a small number that were best hidden from strangers during Stalin's reign: pictures of priests in their vestments and loved ones who had been victims of the repression (her father and grandfather).

38. Guschker, Bilderwelt und Lebenswirklichkeit.

39. For example, see: Viktoriia Semenova and Ekaterina Foteeva, eds., Sud'by liudei. 
When leafing through the illustrated manuscript, one often has the impression of looking at a photo album rather than a text: at times the pictures seem to illustrate the manuscript, and at times the manuscript seems to be nothing more than a long caption for a photo. To fully appreciate this effect and understand the role of objects (including photographs) in the texts, one must keep in mind the connection between the world of objects and how memory functions as well as the specifically narrative properties of photo albums: "Contrary to the stereotype of the remembered past as immutably fixed, recollections are malleable and flexible; what seems to have happened undergoes continual change. Heightening certain events in recall, we then reinterpret them in light of subsequent experience and present need." 40 This can at least partially explain why, for an individual or a social group, certain goods become objects symbolizing a precious and significant past. The past's fragility triggers an unspoken anxiety and a need to give one's memories an intangible foundation. Objects provide this unique service. Those that receive the status of relics become "substitute objects for men and for gods" 41 and "semiophores" 42 : in other words, they refer to an invisible world, ensuring its presence and capacity for action. Family relics do not offer knowledge of the past but, rather, a feeling of what once was-the impression of being able to touch the past. Household relics can play the role of "beacons" of family identity that are seen by the family as sources and sites for the preservation of a lineage's collective memory relating to its past, limits, and prospects. Objects preserved "in memory" serve as pretexts for family communication about "its" history and maintain this status as long as family members feel the need to unite and share a destiny that is as long and uninterrupted as possible.

These statements about family "relics" can be easily applied to private photographs. Moreover, compared to other symbolic objects preserved by families, photographs are for several reasons superior and more persuasive when it comes to identification, communication, and integration. Autobiographical memory and photographic images resemble one another in their fragmentary, incoherent, and subjective character as well as in their unreliability. They cannot be taken as the basis for objective or factual "self" knowledge. They display "a common paradoxical attitude toward reality and fiction." 43 The veracity of a snapshot or an autobiography is as illusory as efforts to use them as truth instruments to satisfy the growing contemporary need to fashion and protect one's "self" and to find and consolidate its place in a constantly changing world. ${ }^{44}$ By placing photographs in

40. Lowenthal, The Past, 206.

41. Godelier, The Engima of the Gift, 108.

42. Krzysztof Pomian, Der Ursprung des Museums: Vom Sammeln (Berlin: K. Wagenbach, 1988; repr. 1993), 50.

43. Suzanne Blazejewski, Bild und Text-Photographie in autobiographischer Literatur: Marguerite Duras' L'Amant und Michael Ondaatjes Running in the Family (Würzburg: Königshausen \& Neumann, 2002), 103.

44. For more details on the illusory nature of biographies, see: Bourdieu, "The Biographical Illusion," trans. Yves Winkin and Wendy Leeds-Hurwitz, in Identity: A Reader, eds. Paul du Gay, Jessica Evans, and Peter Redman (London: SAGE Publications, 2001), 297-303; Blazejewski, Bild und Text, and Guschker, Bilderwelt und Lebenswirklichkeit. 
an album, a snapshot's owner fashions his or her world. Due to the specific place assigned to each photograph in the album, life acquires an order and becomes organized along a chain of cause and effect. The comments one makes about pictures while looking through an album increases their significance. Narratives create sequences: events perceived in particular photographs are organized in an order with a beginning, development, climax, denouement, and conclusion. The story that accompanies an examination of a photo album becomes a tool for constructing one's life and filling in the gaps between the pictures. ${ }^{45}$

It is possible to consider the first version of Khar'kova's memoirs as a detailed account designed to illustrate a photo album, a sort of "photographic text" in which words and pictures support and mutually complement one another while exploiting each media's advantages. ${ }^{46}$ This makes it easier to see the real reasons for including photographs and other documents from the Khar'kova and Pukhal'skaia family archives in the text. Beyond their illustrative function, they present a response to the need to increase the "reality effect" 47 of the past and the veracity of a reconstruction made for both oneself and the family members to whom the memoirs are destined. If historians, as Jacques Le Goff has argued, mobilize their knowledge of sources in order to create a "reality effect," they must be "capable of taking these documents apart in order to conjure whatever produces a reasonable conviction of historical reality." 48 Khar'kova and Pukhal'skaia use their objects with the same goal in mind, incorporating them or quoting a document in a way that introduces a verbal copy into the text. While each author uses her own strategies to endow their memoirs with authenticity, they agree on the need for veracity and believe in it without qualification. This is evident in the epigraphs they insert on some of their title pages: "Established and presented by the narrator by year and month" (Pukhal'skaia); "I describe my recollections as they have remained in my memory" (Khar'kova); "I write as I remember" (Khar'kova); and "I make no pretense of having a literary style" (Khar'kova). Such comments are involuntary testimony to their modesty and constitute a captatio benevolentiae aimed at the reader, who is expected to accept the veracity of their accounts.

Philologists and sociologists would undoubtedly see Pukhal'skaia's and Khar'kova's texts as containing elements of "naïve writing." 49 The term "naïve" has, in this instance, no moralizing or pejorative connotation. "Naïve" memoirs are

45. For more details on the role of photographs in family communication, see: Guschker, Bilderwelt und Lebenswirklichkeit, Marianne Hirsch, Family Frames: Photography, Narrative, and Postmemory (Cambridge: Harvard University Press, 1997).

46. For more details on the specificities of "photographic texts," see Blazejewski, Bild und Text, 58 .

47. Roland Barthes, "L’effet de réel," Communications 11 (1968): 84-89.

48. Jacques Le Goff, Saint Louis, trans. Gareth Evan Gollrad (Notre Dame: University of Notre Dame Press, 2009), xxiii.

49. On the characteristics of "naïve" texts, see: Nataliia Kozlova and Irina Sandomirskaia, "Ia tak khochu nazvat' kino." Naivnoe pis'mo: opyt lingvosotsiologicheskogo chteniia (Moscow: Gnosis, 1996); Kozlova, Sovetskie liudi. 
distinguished, among other criteria, by their authors' lack of professional experience in writing long texts; intended for private use, they are centered on details of daily life and lack serious reflection on their own authenticity. Both cases involve a narrative describing a family's daily life, impressions and feelings as something "authentic" and having a value independent of "great" History, which serves as nothing more than a largely colorless backdrop to family history. The reader is confronted with issues that are not addressed with the same intensity in other kinds of historical sources, such as children's education within the family and relationships between spouses and different generations. The specificities of Pukhal'skaia's and Khar'kova's memoirs allow one to grasp, first, the ways in which family memories or periods that, according to grandparents, were unjustly forgotten, were later "restored to favor"; next, the ways in which evidence of the success of junior family members were remembered; and, finally, the practice of daily oral commemoration in Soviet and post-Soviet families.

\section{Rehabilitating the Past}

Pukhal'skaia's and Khar'kova's archives include the memoirs of other relatives and family members. They used some of these when writing their family chronicles. For instance, the notes taken by Pukhal'skaia's mother Bulgakova, who lived with her daughter's family for almost three decades, had a profound impact on how her daughter wrote her own memoirs. Agniia Ivanovna Bulgakova (1890-1975) was the daughter of Stanislav (Ioann) Bulgakov (1857-1903), a priest, and Elizaveta Vassilievna Popova (1858-1944). According to Bulgakova, Father Ioann raised his two daughters (three others died in early childhood) in a liberal and enlightened spirit and offered them a first-rate secular education. Like her older sister Larisa, Agniia attended high school (gimnaziia) and Bestuzhev women's college. ${ }^{50}$ In 1914, she married Pukhal'skii, a revolutionary, in Kaliazin, on the Volga. The Pukhal'skaia archives contain ten thin notebooks, handmade from quarter sheets of A4 paper, filled with handwriting of almost print-like quality, and decorated with pencil drawings-mostly flowers-in a style characteristic of elite women's diaries at the turn of the twentieth century. ${ }^{51}$ Bulgakova created and carefully decorated these memory-stories containing memoirs from the second half of the 1940s and early 1950s in Tashkent, where her daughter's family was relocated because of the war. She passed the little notebooks on to her eldest sister Larisa, after whose death they were entrusted to Basia.

Bulgakova describes episodes in her childhood and youth that occurred primarily in family settings. Her major themes include Christmas and Easter holidays,

50. On the Bestuzhev women's college in Saint Petersburg and on women's colleges in late imperial Russia in general, see: Anatolii E. Ivanov, Vysshaia shkola $v$ Rossii $v$ kontse 19- nachale 20 v. (Moscow: Akademiia nauk SssR, 1991); Nadezhda I. Kozlova, Iz istorii «henskogo obrazovaniia v Sankt-Peterburge (Saint Petersburg: Petropolis, 1996). 51. Arkhipova, "Karl Marks," 188-89. 
vacations and family visits, the reconstitution of the family household following the evacuation, and family trips to the theater. Bulgakova's memory-stories do not follow a strict chronological order. They consist of tableaux vivants or "Polaroids." The author's memory works in sudden bursts, or, as she puts it, "life seems to be a succession of instants." It is likely that the death of her mother Popova-Bulgakova in Moscow in 1944-while the rest of the family was in Tashkent and unable to care for her in her final moments - was what triggered Bulgakova's decision to write down her memories of childhood and adolescence. Most of Bulgakova's memoirs are devoted to her mother. The first pages of several notebooks are decorated with a crown bearing the name and dates of her "dear little mama." Popova-Bulgakova, who outlived her husband by forty years, devoted every ounce of her energy to raising her daughters. Explaining her capacity for resistance, she told her daughters: "Thinking of you gives me strength." For decades, she supported her daughters' families, particularly that of Agniia, who was also widowed at a young age.

One might well suppose that these recollections were written down from the outset or, if not, that they were committed to paper shortly after they were first told to her grandchildren at night before they went to bed. The last notebook, composed between 1953 and 1954 as what the author deems "a Christmas tale," is entitled "The Arrival from Kaliazin" and devoted to her eldest daughter Larisa (Yaichka). In it, Bulgakova shares her thoughts on her intense engagement with the past.

I "work for my retirement pension." It is under this banner that I work in the workshop of the largest spinning and weaving factory of the Tashkent textile conglomerate.

The second month has already come to an end. For the moment I cannot see the end, as they still have not yet decided to initiate my retirement file. It would be unbearable to remain in a cage filled with never-ending noise for eight hours. But several poems that I repeat to myself as "miraculous prayers," recollections, come to my aid... I have decided to write one down. As an epigraph, I could give it:

"It was a long time ago..."

But without adding the pessimistic lines of a poet whose name I no longer remember, I could not say along with him:

"I do not remember when that happened," etc. For I remember very well, and I always will. There are after all moments when I imagine myself as a kind of Fedia Protasov. ${ }^{52}$ Or as an old and abandoned house, inhabited only by bats, where from time to time one hears the sound of an unhinged shutter and the wind blowing through the cracks. It won't be exact. But it happens.

Through all these past years, I have asked myself the question: where does this pessimism come from, this pessimism which makes it impossible to feel joy and which ensures that the specter of distrust and doubt casts its shadow over almost everything, which weaves its web over everything, which maintains an entire arsenal of threats and premonitions 
that it unleashes like a pack of dogs at the slightest opportunity. Where does it come from? Where?

It is likely that the reason is of a material nature. One has only to breathe deeply (the "medicine" that Lara gave me last year) for optimism to burst forth, I feel it physically, as if something blew away a "cloud of poisonous fumes." But the problem is that I do not always manage to make myself breathe in a salutary way...

Yes. So, let us quickly turn to my memories. ${ }^{53}$

Bulgakova was drawing up a balance sheet. She found it necessary to "work toward her retirement" and to struggle the best she could against her growing pessimism and fatigue with life. She had nothing material remaining from the past, save for a few silver spoons. Her mother was dead and the 1941 Kalinin fire had destroyed every material testimonial to her youth and all traces of the dead. She then began to fight for her own past, driven by a will to safeguard its memory and pass it on to her family. She devoted her commemorative work to unearthing the past, which she cherished and believed had been unjustly forgotten by Soviet society. Her notebooks overflow with detailed descriptions of times she spent in properties owned by her parents' friends, the recollection of which was disturbing and even dangerous under late Stalinism. Her deceased husband Pukhal'skii also occupies a major place in her memoirs. Despite the fact that several streets in Kalinin bear his name, she presumed that they had been destroyed by bombardments and the German occupation of the city. Furthermore, the names of most revolutionaries of Lenin's generation had fallen into oblivion during the Great Terror of 1937-1938. As a Pole and a former social democrat, Pukhal'skii had little chance of surviving this damnatio memoriae. ${ }^{54}$ Bulgakova's memories provided the basis of her daughter's reconstruction of the family's prerevolutionary past, particularly her father's. Under Khrushchev, Pukhal'skaia, with the help of her mother, who still spoke some Polish, reestablished contact with the Polish branch of the family, which had dispersed for safety reasons in the 1930s. Remarkably, the author mentions no conflicts between the Polish and Russian versions of family memory. ${ }^{55}$ I was unable to find out if this was due to the desire to gather missing bits of information from each side and thus "complete" the family history, deliberately avoiding touchy

53. Agniia Ivanovna Bulgakova, "Priezd v Kaliazin. Priezd v Tver" (unpublished manuscript, Tashkent, 1954), notebook no. 10.

54. On the scope of the repressions directed at Soviets of Polish origin in 1936-1938, see Adam D. Rotfeld and Anatolii V. Torkunov, eds., Belye piatna-chernye piatna: Slozhnye voprosy v rossiisko-pol'skikh otnosheniiakh (Moscow: Aspekt Press, 2010), 122-25.

55. However, a trip to Yerevan by one of Pukhal'skii's Polish relatives in the summer of 1968, when Soviet tanks were invading Prague, was vigorously discussed by him and Bulgakova (or Geta, her family nickname): "Matei kept repeating emotionally: 'It's an occupation, an occupation.' Like a Soviet who trusts official reports, Geta replied: 'It's international assistance.' Their conversations often ended in arguments. Naturally, Matei was right." Pukhal'skaia, "Zhizn' sem'i," 140. That she agreed with Matei in text written in the 2000s does not mean that Pukhal'skaia held the same opinion in 1968. 
issues, or if it was instead due to sustained silence in the text of the memoirs themselves.

Khar'kova, for her part, engaged in rehabilitating the past in the strictest sense of the term: she had to salvage the reputations of her father and her grandfather, who were victims of the Great Terror, and preserve their memory for the family. In these accounts, she quotes verbatim documents found in her archives. In particular, she quotes a letter sent to her mother by Khar'kov's cellmate, who wrote: "On July 5, 1940, at 11 in the morning, Afanasii Ivanovich Khar'kov died from tuberculosis. He was conscious and talking about his family when he died." 56 His daughter attached to the text of these memories a portrait drawn by the prisoners, which the family received after Khar'kov's death, in addition to photographs, including the family snapshots he kept on him. Khar'kova managed to collect and use in her memoirs a significant number of documents relating to the death of her grandfather, Father Narsky, at the age of seventy. At the beginning of Perestroika, two of her children tried to learn more about his fate and received, as Khar'kova writes, "identical responses, which stated that their grandfather died in 1943 of kidney failure in the prison in Svobodny, a town near Blagoveshchensk. The day and month were not provided. As we later found out, this was an insolent lie and nothing more than a mockery." 57

It was not until ten years later, in the spring of 1996, that Narsky's family located the prosecution's file, which included an account of his interrogation, extracts from the verdict issued by a troika from the federal NKVD, and extracts from the executive order. A copy of the file is included in Khar'kova's archives and she cites some of its contents in her memoirs: "Extract from the minutes of March 2, 1938: 'It was decided to shoot Narsky Vladimir Alekseevich.'” An extract from the sentence reads: "The March 2, 1938 decision of the troika of the NKVD's Moscow regional office to execute Narsky, Vladimir Alekseevich was carried out on March 8, 1938." The file also includes the letter her grandmother sent to Beria, although it is incomplete because an employee of the Memorial society did not have time to fully recopy it. "As soon as we learned that he had been sentenced and executed," writes Khar'kova, "March 8 became for all his descendants the day to commemorate the memory of their grandfather, who had been shot in the 'Butovo zone." ${ }^{58}$ Khar'kova had felt a desire to protect her grandfather from unjust attacks as far back as her childhood, when her schoolteacher first presented her with the official interpretation of the events. She describes the incident in her memoirs:

At school, they told us how religion, the Church, and religious holidays were dangerous for the people and how priests_- "popes," as they were called-were bad. I was disturbed. How could this be possible? Grandfather was so good! And all the religious holidays were so lovely! But I did not dare contradict my teacher. In 1930, they forbade the Christmas

56. Khar'kova, "Vospominaniia rossiianki," 239. 
tree $^{59}$ : for the first time in my life, we did not have a tree at Christmas. How I missed it, thinking back to the trees at Ermolino! The teacher explained that the forest would die because of all the trees that had been cut down. This was perhaps true? I thought about it for a long time without being able to understand with my little child's brain. Where did the truth lie? I knew that Russians had had trees for Christmas and the New Year for ages. Did they really destroy forests? None of these thoughts left me in peace. The church at Paveltsev was closed, and shortly afterwards we learned that the one in Ermolino was also closed, that grandfather and grandmother had been dekulakized, and that their house with all their goods, cow, and horse, had been taken! Why was all this happening? Where and how would they live now? I was sad and unable to understand what they had done wrong. ${ }^{60}$

\section{Memories of Children Growing Up}

Childhood is a central theme of family chronicles. It echoes Soviet debates about the role of the family and schools with regard to education and families' efforts "not to become chameleons" and follow "their own [educational] rules" in the interest of self-preservation. ${ }^{61}$ But there is another obvious explanation of the central place of stories about children in women's memoirs. (Auto)biographical memoirs are a way for authors to prove retroactively to themselves and potential readers that their lives were not lived in vain. At the end of her memoirs, Khar'kova describes her sense of fulfillment with life: "I consider that I have lived a happy life, despite a lack of material comfort, sadness resulting from great loss, and prolonged separation from my beloved. Ever since I was little, I have been surrounded by the love and, later, the respect of everyone I have met. I have known great love and the worries and joys of motherhood. Is this not happiness?!"62

Children and their successes are powerful narrative motifs in stories about family happiness. Pukhal'skaia and Khar'kova describe in detail the development of their three children and their educational strategies. They recount their families' favorite games, the books they read individually or collectively, the discussions they provoked, the role of music and choral singing, poetry written to honor family members, and the spectacles and concerts the family attended. If the origins of this inclination for "high" culture lie in the prerevolutionary period, by the 1930 s,

59. On the prohibition of Christmas trees in the context of Soviet antireligious campaigns, see Alla Sal'nikova, Istoriia elochnoi igrushki (Moscow: Novoe literaturnoe obozrenie, 2011). 60. Khar'kova, "Vospominaniia rossiianki," 117.

61. On Soviet childhood, see: Jenny Brine et al., eds., Home, School, and Leisure in the Soviet Union, (Boston: Allen \& Unwin, 1980); Valerii V. Bogdanov, Istoriia shkolnykh veshchei (Saint Petersburg: Karo, 2003); Alla Sal'nikova, Rossiiskoe detstvo v 20 veke: Istoriia, teoriia i praktika issledovaniia (Kazan: Kazanskii universitet, 2007); Maria V. Osorina, Sekretnyi mir detei v prostranstve mira vzroslykh (Saint Petersburg: Piter, 2011); and Catriona Kelly, Children's World: Growing Up in Russia, 1890-1991 (New Haven: Yale University Press, 2007).

62. Khar'kova, "Vospominaniia rossiianki," 385. 
this was encouraged and systematically imposed by the Soviet state. ${ }^{63}$ Both families present the results of their children's education in identical terms. According to Agniia Stefanovna, "Basia and Geta [Bulgakova's nickname] could be proud of their children-intelligent, well-educated people in whom they had invested their entire lives." 64 Vera Afanasievna's memoirs betray the same pride: "With time, all our children became greatly respected and acquired authority in their work." 65 Pukhal'skaia feels indebted to her mother Bulgakova for her detailed memories of the minutest details of her children's lives. From 1945 to 1953 , her mother recorded with a chronicler's precision her grandchildren's actions, reactions, and expressions. The great chest in which Agniia Stefanovna kept her most precious documents includes five handmade notebooks made up of quarter A4 sheets entitled "Basia's Children" and consisting of both rough and clean drafts in addition to two "Picture Books," which are also handmade in the same format and filled with children's drawings. The covers explain that the drawings are by Bulgakova's grandchildren, Stefan and Elga Khazanov, who dedicated them to "dear Yaichka," as Bulgakova's older sister Larisa, who lived in Moscow, was known. "Basia's Children" draws inspiration from Elena's Children, an English book translated into Russian in the late nineteenth or the early twentieth century and which consisted of a mother's descriptions of her children. In "Basia's Children," amusing anecdotes about the lives of her grandchildren are interspersed with their clever remarks and drawings as well as poems written by three of the family's adults (Bulgakova, Pukhal'skaia, and Khazanov) for the children (Stefan, Elga, and Pavel) on their birthdays. The goal of these notebooks was to record events in the children's lives for relatives who stayed in Moscow. Bulgakova's notebooks and memoirs were indeed sent to Moscow, before being returned to Pukhal'skaia upon her death.

In "Basia's Children," ideologically neutral descriptions of New Year's festivities, family games, and childish mischief overlap with patriotic compositions-obviously recopied from schoolbooks-devoted to Moscow and the Fatherland, written according to the strictures of late Stalinism. One of the "Basia's Children" notebooks, dated 1951-1952, includes an essay by her eleven-year-old daughter entitled: "Why I Love My Fatherland." It is an assortment of ideological clichés about

63. On the formation of Soviet pedagogical norms in the 1930, see: Dietrich Beyrau, Intelligenz und Dissens: Die russischen Bildungsschichten in der Sowjetunion 1917 bis 1985 (Göttingen: Vandenhoeck \& Ruprecht, 1993), 73-155; Kelly, Children's World. In the chapter of her memoirs devoted to the years 1947-1951, Pukhal'skaia provides the following details: "We lived all those years in Tashkent with little information, as news about the country and the world came only from the local radio station and one Russian newspaper, Pravda of the East (Pravda Vostoka). Only in early 1948, when Abram received a Vostok radio set for the hard work he had done in 1947, were we able to listen to the Moscow news (which in fact was scarce and carefully controlled). By changing the set's frequency, we could get music and concerts from as far away as Brazzaville in the French Congo, which in itself was a miracle. Since then, we have given greater attention to geography in the children's education. We hung large geographical maps of every part of the world on the walls." Pukhal'skaia, "Zhizn' sem'i," 73. 
the joys of life in the Soviet Union. The happiness of Soviet children is compared with the dreary tsarist past and the suffering of children in Capitalist countries. It also evokes wise Stalin, "beautiful Moscow," and "the best city in the world."66 Several fragments of "Basia's Children” were incorporated into Pukhal'skaia's memoirs. When describing her children's lives, they are paraphrased or quoted verbatim without quotation marks, although they occasionally reference the author, particularly in the case of poems. Yet the children's texts that exhibit loyalty and commitment to the Stalinist regime are never mentioned in their mother's memoirs. Once again, this fact confirms that the veracity of (auto)biographies is illusory, since biographies and autobiographies are inevitably based on selection, manipulation, and silence. These practices are not the expression of a deliberate maliciousness on the part of their authors, but the natural result of the social and cultural stakes of writing biographies: outlining a successful life.

\section{Family Discussions About the Past}

In "Memoirs of a Russian," Khar'kova describes a "terrifying" event that occurred in a village on the Volga, most likely in 1935.

A river passed very close to the village and there was a bridge that crossed it. It was said that under this bridge there lived a monster that would capture children. All the children were terribly afraid of the bridge. One day, the kids in my class said that I would not dare to go back and forth on the bridge at night when it was dark. I said that I could do it easily. When it was almost dark, our whole class gathered there, everyone was curious to see if I would be able to cross the bridge. To prove that I had reached the other end of the bridge, I was supposed to cut off a branch of the weeping willow that grew there next to the bridge. I walked, fully expecting to be pulled beneath the ground-that's how terrified I was. I turned around and saw no one, I was surrounded by silence, the drizsle and the water murmuring beneath the bridge. I felt how much my hands and my legs and soon my whole body were trembling. I remembered one of my father's stories, how he had torn a lily branch from the middle of a cemetery and decided that I should be worthy of my father! I overcame my fear, I quickly crossed the bridge, I tore off a branch, turned around, and ran. In the middle of the bridge, I started walking so as not to show my fear. There was not a sound around me, no one was following me. It was with pride that I handed over the torn branch to my classmates. From that day on, the kids had a lot of respect for $m e^{!^{67}}$

There is nothing unusual, it would seem, about this account: the children are prepared to touch what scares them in order to tame their fears. ${ }^{68}$ But to what does

66. Basiny detki, 5, 1951-1952, in Pukhal'skaia, "Zhizn' sem'i."

67. Khar'kova, "Vospominaniia rossiianki," 159-60.

68. On the role of "terrifying stories" in overcoming childhood fears, see Osorina, Sekret-

nyi mir detei, 77-89. 
the story of the father and the lily branch refer? The author speaks of it in the early pages of her memoirs, in which she recounts her father's involvement in the Civil War.

One day, a detachment of Red Army soldiers stopped near a village cemetery in the middle of which grew a splendid bush of white lilies. The soldiers told my father that he would not dare cut a branch at midnight. My father replied that he would do so without difficulty. So at midnight, he headed toward the bush through the cemetery. At the very moment when he extended his hand to cut off a branch, there appeared before him a white ghost, much bigger than a human being. Without thinking for long, my father pulled out his pistol and fired. The ghost fell to the ground, while my father broke off a lovely white branch and returned to his comrades who were waiting for him with curiosity. When my father explained that a ghost had appeared before him and that he had shot it, his comrades exclaimed: "Have you lost your mind? It was our commissar!" They ran to the cemetery and lifted up the commissar's sheet; he was dead. It turned out that the entire show had been conceived by the commissar himself. Before my father arrived, he had hidden himself behind the bush near the tombs and, when he saw my father, he climbed on to stilts and covered himself in a sheet. The commissar was very likeable, a man with a great heart and a commander beyond reproach. The bullet had struck him in the heart. Everyone was crying, while my father sobbed and pulled out his hair. He adored this commissar and was close friends with him. Throughout his life my father often recalled this tragedy. He was never punished for this murder. ${ }^{69}$

Before he was arrested in 1936, Khar'kova had learned firsthand that her father, who was seventeen at the time, had killed a military commissar during the Civil War without consequences. This story does not figure in the Civil War's official heroic accounts. ${ }^{70}$ Yet its primary protagonist recounted it on several occasions to his child during the troubled period of the 1930s. This fact contradicts the thesis maintaining that, under Stalinism, adults concealed the past from their children. Family memories provide a sense of the topics that are difficult to approach through other sources, such as the contents of conversations devoted to the pasts of Soviet families. Ultimately, this past does not extend back very far. ${ }^{71}$ While undertaking her genealogical research, Pukhal'skaia was unable to find reliable information before the late nineteenth century and more rarely the middle of the nineteenth century. Only while researching the aristocratic Pukhal'skii was she able to find information on her immediate ancestor, Dominik Pukhal'skii, with the help of her

69. Ibid.

70. On the creation of images during the Civil War, see: Narsky, Zhizn'v katastrofe; Narsky, "Bürgerkrieg_zur Konstruktion eines Gründungsmythos im frühen Sowjetrussland (Ural 1917-1922)," in Der Krieg in den Gründungsmythen europäischer Nationen und $\operatorname{der}$ USA, eds. Nikolaus Buschmann and Dieter Langewiesche (Frankfurt and New York: Campus, 2003), 320-30.

71. On the narrow chronological framework of family memory in contemporary Russia, see: Langenohl, Erinnerung und Modernisierung; Narsky et al., Vek pamiati; and Narsky, Fotokartochka na pamiat'. 
Polish family. In her memoirs, Khar'kova admits that she was unable to trace her ancestry on her mother's and father's sides beyond her grandparents, despite her efforts.

Forms of conscious and goal-oriented oral exchanges about the past were not very diverse. According to interviews I conducted, grandparents' stories about their youth are the most frequent and apparently the most effective. Grandchildren often hear these stories before spouses or children. The most organized form of narration is memories that take the place of bedtime stories. This is how Bulgakova and Khazanov created and preserved the family oral tradition. Khazanov's account of his childhood in the late 1940s was included in "Basia's Children"-though as fragments—so that it could be told to children. Only in the 1970s did he admit to his grandchildren that he once belonged to a criminal gang. Another form of communication is memories recounted at the dinner table during family holidays. According to Khar'kova, this is how family memory was preserved in the large Narsky family, which gathered regularly at his home and then, after his death, at his wife's home in the village of Ermolino. Khar'kova writes the following about the reunion at Narskaia's home on her saint's day, December 22, 1945, at a time when their contemporaries believed that a period of liberalization was about to begin:

How happy grandmother was! Everyone was exchanging news, we remembered how we all lived together in the parental home, how we celebrated religious holidays, sang, helped grandmother organize spectacles, picked mushrooms, caught fish and crawefish and many other things! Of course, we brought up our memories of grandfather(!), sang his favorite songs: "Dawn, pretty dawn, with many shining stars!" ["U zori u zoren'ki mnogo iasnykh zvezd"], "Sounding the evening bells" ["Vechernii zvon"], "The lake is sleeping" ["Ozero spit"].72

Exchanges relating to written memories, which are relatively rare in Russian family archives, are a less frequent form of family oral communication. Pukhal'skaia's and Khar'kova's texts are not aimed at the broader public. They were conceived for internal family usage, as a form of memory preservation. Children and grandchildren constitute the circle of potential readers addressed by both memoirists. They are the first—and most important—readers and commentators of these texts. Readers' reactions were varied. The memoirs attracted interest and were generally well received. Readers' reactions, however, could not have been unanimous. By Khar'kova's own admission, her children were more interested than her grandchildren, some of whom never read them. Still, Vera Afanasievna displays understanding and optimism. She thinks that a time will come when the grandchildren will be interested. Pukhal'skaia, who is less optimistic, worries that the memoirs and archives she gathered will be abandoned for decades. It is difficult to say with any certainty if this lack of interest in their grandmothers is due to the grandchildren or contemporary Russia's general loss of interest in its past. Yet one might

72. Khar'kova, "Vospominaniia rossiianki," 363-64. 
well suppose that the growing nostalgia for all things Soviet on the part of generations that came of age following the collapse of the Soviet Union will spark curiosity in memoirs devoted to the twentieth century, like those by Pukhal'skaia and Khar'kova.

\section{Was There Something Specific about "Soviet" Family Commemoration?}

In family memory, the Soviet and pre-Soviet periods were constantly enmeshed: family members socialized before the revolution contributed greatly to memory formation; the family memorial culture of two Soviet (and post-Soviet) families took the form of nineteenth-century domestic pedagogy; the norms of family education combined Soviet "cultural revolutionary" pathos with prerevolutionary standards of "culture" (kul'turnost'); and pre-Soviet practices of diary keeping and amateur attempts at writing children's literature contained Soviet content. Families' prerevolutionary pasts were known and discussed in family circles even before Gorbachev's glasnost. Does this rather narrow body of sources make it possible to draw general conclusions about the culture of commemoration in the Soviet Union and contemporary Russia and thereby discover a specifically Soviet form of family commemoration? ${ }^{73}$

The writing and reading of memoirs increase during periods of crisis. The circumstances in which the Pukhal'skaia and Khar'kova family chronicles appeared follow this pattern. Indeed, as periods of profound social and political transformation come to an end and yesterday's events are viewed as part of an irreversible past, communities possessed of a strong desire to understand these changes and harmonize collective expectations with individual worldviews feel a pressing need to take stock of their situation. This need has a sociocultural equivalent at the micro level of individual development: the desire to recount the story of one's life generally manifests itself in the second half of one's life, when signs of aging become evident. These two dimensions - the individual and the collective-coincide and become inextricably enmeshed in Pukhal'skaia's and Khar'kova's memoirs. The collapse of the Soviet Union, in which they had lived most of their lives, the rupture of the 1990 s, the death of most of their contemporaries, friends, and relatives - all of these factors fed their desire to collectively and individually assess themselves as well as create and retroactively justify a successful and happy life. This sense of familial joy required material proof. The world of objects thus offered a tangible hold on the past, the traces of which were carefully assembled and classified in family archives by aging widows and later included in their own memoirs. Yet it is unlikely that the heroines of this article would have undertaken to write these family chronicles during Perestroika. They collected their documents

73. On the difficulties of identifying the "Soviet" character of Soviet culture, including the culture of manipulating the past, see: Langenohl, Erinnerung und Modernisierung; Narsky, Fotokartochka na pamiat', 369-77. 
for the most part at a time when the past was being radically revised: "As early as the late eighties, representations of a hitherto hidden past were rendered public, presented as alternative visions of history, creating the illusion of a 'true' past (to the extent that it contradicted official history and was kept secret and hidden from inopportune eyes) that was, as it were, protected from nefarious ideological and political influences. Some of these 'discoveries' and 'hidden stories' then became a new form of official historical discourse, justifying in a sometimes aggressive way the creation of new (national and other) identities." 74

The beginning of Pukhal'skaia's and Khar'kova's work coincided with the Brezhnev era, which is known for its complicated relationships between public and private commemorative practices. During the Khrushchev Thaw, the supreme leadership initiated a short-lived public discussion of the "inglorious" Soviet past associated with Stalin. This process threatened the hegemony of state and party, and since the Brezhnevian leadership needed to compensate for its inability to build a Communism for 1980, it decided to make use of the country's "glorious past." A paradoxical situation resulted: while official propaganda sang the praises of the Soviet past when Stalin ruled judiciously and the gulag and violence never existed, families preserved in their home libraries copies of Aleksandr Solzhenitsyn's One Day in the Life of Ivan Denisovich and Ilya Ehrenburg's People, Years, Life, countless editions of which were published in the 1950s and early 1960s. Grandparents continued to tell their grandchildren family stories that they kept silent in Stalin's day and which contradicted school textbooks. Jokes (anekdoty) were used to poke fun at officials long before Perestroika. The contradictions and multiplicity of commemorative discourses during the late Soviet Union gave families a certain amount of leeway to establish their own history as an alternative past.

The "duration" of family memory in the Soviet Union is also specific: the Soviet and post-Soviet appeal to the past has fairly strict boundaries. In most cases, family memory in contemporary Russia only extends as far back as the late nineteenth century; more rarely, to the mid-nineteenth century (for example, families with priests as ancestors, like Khar'kova); and, very exceptionally, to the late eighteenth century (as with Pukhal'skaia's family and their noble origins). ${ }^{75}$ This "short" family memory and tenuous handle on ancestry beyond the generation of one's grandparents is explained by upward social mobility in the twentieth century and declining of bonds of kinship. In the Soviet Union, particularly under Stalinism, the brevity of collective memory was further shortened by the state's insistence-which was not always respected-on silencing families' prerevolutionary origins: the tsarist period was officially presented as the dark prehistory to the heroic present and the radiant future, while censoring the pre-Soviet origins of one's family was also a necessary condition of survival.

Universal (from the standpoint of European culture) and typically Soviet characteristics of family history can be distinguished in cross-generational discussions of the family past. A generation, as an emotional community sharing certain

74. Khmelevskaia, "Vvedenie," 8. 
core traits, illusions, values, and memory, inevitably lives in tension with other, similar communities. ${ }^{76}$ Strained relationships between generations can explain why collaboration in various spheres of social life can skip the generation lying between "grandparents" and "grandchildren."77 This observation also applies to children, for whom grandparents are particularly important compared to their parents. The close connection between grandparents and grandchildren can be explained by the older generation's conscious desire to share their past at a time when their own children lead independent lives and look down condescendingly on the confessions of "old folks." It is no surprise that grandchildren become the primary audience of their grandparents' experiences.

The pattern of breakdown in cross-generational relationships is very apparent in Central and Eastern European societies, which were deeply traumatized by their twentieth-century experiences. This is the case in Russia and Germany, where trusting relationships between parents and children were complicated by state and societal taboos about the troubled past, which it was risky to even mention. ${ }^{78}$ The distinctively "Soviet" character of family commemorative practices- the "brevity" of family memory, the relative infrequency with which it is written down, the difficulties in having two consecutive generations discuss the past, and communication between grandparents and grandchildren-have less to do with their content than with the context of coming to terms with the past and can be explained by external circumstances, such as the "frameworks of memory" that are publicly prescribed by the state and the pressures of official historical discourse. The burden of these circumstances, however, diminished significantly after Stalin's death.

Yet I would like to indulge myself with one final question: did the Stalinist era condemn the familial past to total oblivion? The memoirs, particularly those of former aristocrats, ${ }^{79}$ first begun well before the 1917 revolution and which were

76. For more details on the conflicts and tensions between generations, see: Heinz Bude, "Die biographische Relevanz der Generation," in Generationen in Familie und Gesellschaft, eds. Martin Kohli and Marc Szidlik (Opladen: Leske/Budrich, 2000), 19-35; Hirsch, Family Frames; Yurii A. Levada, "Pokoleniia 20 veka: Vozmozhnosti issledovaniia," in Ottsy $i$ deti. Pokolencheskii analiz sovremennoi Rossii, eds. Yurii A. Levada and Teodor Shanin (Moscow: Novoe literaturnoe obozrenie, 2005), 32-60.

77. I refer the reader to my previous work: Igor Narsky, "Refleksii o refleksiiakh, ili detskie istorii vzroslogo istorika," in Detstvo v nauchnykh, obrazovatel'nykh i khudozhestvennykh tekstakh. Opyt prochteniia $i$ interpretatsii, ed. Alla Sal'nikova (Kazan: izdatel'stvo Kazanskogo universiteta, 2010), 55-60; and Narsky, “'Budushchee-v-proshlom': Publichnoe prodvizhenie (sovetskikh) semeinykh 'relikvii' v optike kul'turno-pokolencheskikh razryvov," in Puti Rossii. Budushchee kak kultura: prognozy, reprezentatsii, stsenarii, eds. Marina G. Pugacheva and Victor S. Vakhshtain (Moscow: Novoe literaturnoe obozrenie, 2011), 322-38.

78. For an impressive comparative analysis of Russian and German development over the twentieth century, see Karl Eimermakher et al., eds., Rossiia i Germaniia v 20 veke (Moscow: Airo-XXI, 2010), 3 vols.

79. For example, see: Liudmila V. Shaporina, Dnevnik, 2nd ed. (Moscow: Novoe literaturnoe obozrenie, 2012), 2 vols.; Konstantin N. Teplukhov, Memuary: 1899-1934 (Moscow: Novoe literaturnoe obozrenie, 2011). 
still being worked on into the 1940 s and even the 1960 s, provide no easy answer. ${ }^{80}$ For their authors as well as for Bulgakova, whose memoirs are included in the archives of her daughter Pukhal'skaia, obstinate diary keeping was dictated by the existential need to remain oneself and avoid being lost in rapidly changing, unstable, blurry, and often hostile circumstances. Respect for the past was seen as a prerevolutionary tradition, contrasting with the "amnesia" of Soviet politics and ideology. ${ }^{81}$ Consequently, one might well suppose-and scattered evidence supports this hypothesis - that the motives for writing ego-documents could be greater than the circumstantial obstacles, fears, and risks that are always deemed specifically Soviet phenomena. The level of opposition that existed under the Soviet Union is perhaps underestimated, ${ }^{82}$ and it is likely that the number of personal testimonials preserved in closed archives and those, which are even more numerous, that are spread across private archives and continue to play a role in family identification, communication, and solidarity cannot be realistically determined.

\section{Igor Narsky South Ural State University}

80. On the daily lives of representatives of prerevolutionary elites in the Soviet Union, see: Timo Vihavainen, ed., Normy i tsennosti povsednevnoi zhizni: stanovlenie sotsialisticheskogo obrawa shizni, 1920-1930 gody (Saint Petersburg: Neva, 2000); Sofiia Chuikina, Dvorianskaia pamiat': "byvshie" v sovetskom gorode (Leningrad, 1920-e-1930-e gody) (Saint Petersburg: Izdatel'stvo Evropeiskogo universiteta, 2006).

81. For example, see Shaporina, Dnevnik, 1:225. Her notes from 1938 are as follows: "Previously, objects were handed down from one generation to another, archives were preserved, and history was created. Now, the present negates the day before, today we shoot yesterday's leaders, and the entire past is destroyed in the minds of the young. My papa taught me to honor all those little pieces of paper, those notes from the past." 82. For example, see Maria Ferretti's important thoughts on workers' protests against Stalinism during the interwar years, which radically challenge conventional views about the extent of opposition in the USSR in the late twenties and early thirties: Maria Ferretti, "Iaroslavskii rabochii Vasilii Ivanovich Liulin,” Rossiia XXI 5 (2011): 154-89. 